UHERO

THE ECONOMIC RESEARCH ORGANIZATION AT THE UNIVERSITY OF HAWAIII
ASSESSING THE POTENTIAL FOR FOOD AND ENERGY SELF-SUFFICIENCY ON THE ISLAND OF KAUAI, HAWAII

BY

KARL KIM, KIMBERLY BURNETT, AND JIWNATH GHIMIRE

Working Paper No. 2015-11

July 1, 2015 


\title{
Assessing the potential for food and energy self-sufficiency on the island of Kauai, Hawaii
}

\author{
Karl Kim, Ph.D. \\ Department of Urban and Regional Planning \\ University of Hawaii at Manoa \\ 2424 Maile Way \\ Honolulu, HI 96822, USA \\ Ph.1-808-956-0601 \\ Fax.1-808-536-9110 \\ Email.karlk@ hawaii.edu \\ Kimberly Burnett, Ph.D. (Corresponding Author) \\ University of Hawaii Economic Research Organization \\ University of Hawaii at Manoa \\ 2424 Maile Way \\ Honolulu, HI 96822, USA \\ Ph. 1-808-956-8068 \\ Fax: 1-808-956-4347 \\ Email.kburnett@hawaii.edu \\ Jiwnath Ghimire \\ Department of Urban and Regional Planning \\ University of Hawaii at Manoa \\ 2424 Maile Way \\ Honolulu, HI 96822, USA \\ Ph. 1-808-956-6296 \\ Fax. 1-808-956-6870 \\ Email.jiwnath@hawaii.edu
}




\begin{abstract}
Food and energy security are major concerns in the Pacific and around the world. They are key planning priorities in the state of Hawaii as well. Approximately 90 percent of energy and food resources are imported to Hawaii from the continental USA or other parts of the world. While food and energy independence is a goal in many jurisdictions, assessment of the potential for local food and energy production is lacking. Research is needed to examine how agricultural lands can be used to meet food and energy demands, particularly on islands where land is limited. The contribution of this paper is the development of a communityorientated method for evaluating and prioritizing lands for food and energy self-sufficiency, based on local preferences and production possibilities. Based on a review of the literature, community meetings, and expert interviews, three scenarios were developed to assess food and energy production possibilities on Kauai. The first scenario considers maximum food production, the second assigns equal importance to food and energy production, and the third scenario maximizes energy production. This work broadens policy discussions regarding the preservation of agricultural lands on small islands.
\end{abstract}

Keywords: Food self-sufficiency, energy production, agricultural zoning, GIS, Kauai

\title{
Highlights
}

- We develop a process for operationalizing legislation requiring the prioritization of agricultural lands;

- through a stakeholder process, the significance of food and energy self-sufficiency was identified, and a method for assessing these goals was developed and applied to Kauai, Hawaii;

- three scenarios are examined: complete food self-sufficiency, a balance between food and energy production, and a focus on maximizing energy production;

- our analysis shows that while currently zoned agricultural lands on Kauai are capable of meeting the nutritional needs of the current population, it is not possible to meet the complete energy demands of the island unless the quality of agricultural lands is compromised.

\section{Introduction}

Food and energy security are important goals in the U.S. and the rest of the world, especially, within island communities (Sharma, 2006). With increased interest in biofuel production, the tradeoff between food and energy production will continue. Over time, more agricultural land will be used for energy production (Johansson and Azar, 2007). While there is not a consensus regarding a definition of food security, there are many arguments that it should be part of efforts to increase sustainability (Feenstra, 1997) and resilience (McGrarrell, 2005). With an appropriate combination of food and energy crops, farming can minimize greenhouse gas emissions from the agricultural sector while improving local food self-sufficiency (MacRae et al., 2010). Others question the benefits of localizing food and energy (Cunningham, 2010; Peters et al., 2009b). Research regarding the feasibility of reaching goals of food security has become more prevalent as communities increasingly demand locally-sourced food. Peters et al. examined the ability of New York State to localize food production, and found that with the exception of New York City, most smaller cities could theoretically have most of their food needs sourced in-state (Peters et al., 2009a). 
Thompson et al (2008) conclude that based on dietary needs, San Francisco could feed itself from what is produced in farms and ranches within 100 miles. Based on land requirement estimates, Erickson et. al., (2013) find that Chittenden County has the necessary land to produce most of its local food demands. A similar study in Oakland, concluded that available land could provide between 5 and 10 percent of the city's vegetable needs (McClintock and Cooper 2009). Kremer and DeLiberty examined urban Philadelphia using physical, administrative, and zoning data and determined the potential for food production (Kremer and DeLiberty, 2011). Another study in Waterloo, Canada analyzed food consumption and calorie intake patterns projecting required acreage of land to meet food requirements for the population by 2026 (Desjardins et al., 2010).

There is much research on energy self-sufficiency that focuses on biofuel and solar production. Biofuels are categorized as generations 1(G1), 2(G2), and 3(G3) (Murphy et al., 2011). First generation biofuel (G1) is produced from food crops (Murphy et al., 2011; Sims et al., 2010). Second generations biofuel (G2) is produced with lingo-cellusic feedstock and third generation (G3) biofuel is produced with the use of micro algae, and is the most advanced form of biofuel (Murphy et al., 2011). This study focuses mainly on $2^{\text {nd }}$ generation biofuel production. Compare to G1 biofuel, the process of producing G2 biofuel offers a tremendous reduction in environmental costs and conflict between food and energy production (Hill, 2007). Second generation biofuel technologies and energy crops are expected to be more efficient than first generation (López-Bellido et al., 2014). Furthermore, there is growing attention surrounding research and development of ethanol production in Hawaii including a legislative mandate of achieving 20\% energy from renewable sources by 2020. G1 technology presents the issue of competition of crop use for biofuel and food. But with $\mathrm{G} 2$ technology, competition is minimized because raw materials for G2 biofuel production are not food crops; instead it uses remains and byproducts of food production and any other woody or grassy biomasses. It has been shown that cellulosic energy crops can be beneficial to food crop farming by controlling pest, protecting biodoversity, reducing soil erosion, reducing crop management, and minimizing transportation energy cost (MacRae et al., 2010). There are several crop types for biomass conversion to ethanol globally. The primary categories are grassy (sugarcanes, banagrass, guinea grass, sweet sorghum, etc.), and woody (Eucalyptus, leucaena, etc.) biomass for ethanol production. There is extensive research on suitable biomass crops for ethanol production in Hawaii. Biofuel crops considered in this study are either in commercial production in Hawaii or in the research and development phase. Euculyptus is in commercial production and banagrass, leucaena and oil palm are in the trial phase in Hawaii (College of Tropical Agriculture and Human Resources, 2009). The research and trials for banagrass and leucaena have been successful for commercial production (Keffer et al., 2009). We also consider oil palm, which has same type of water and soil requirements as banagrass.

Transportation is a key sector for biofuel use. Biofuels, however, account for use less than $2 \%$ of total global road transportation fuel and the use is concentrated in Brazil, European Union and the US (Johnson and Silveira, 2014). There are innovations in the automotive technology to accommodate biofuels, with the mix of biofuel with gasoline being the most common. There are E10, E15, and E20 technologies that accommodate a 10, 15, and 20 percent mix of biofuel with gasoline. Hawaii has established a legislative mandate that the state will replace highway fuel use by $10 \%$ with alternative fuel by $2010,15 \%$ by 2015 and $20 \%$ by 2020 (Keffer et al., 2009; State of Hawaii, 2008a, b). In the case of solar energy, photovoltaic is the most suitable technology of sustainable energy in the world and is rapidly growing (Razykov et al., 2011). It is widely available, inexhaustible and the cleanest of all energy sources (Parida et al., 2011). Hawaii has abundant sunshine for solar electricity and it 
has higher than average electricity prices (Department of Business Economic Development and Tourism, 2006). In Hawaii, local production of renewable energies may be particularly important because it is the most isolated landmass in the world and more than $87 \%$ of its energy is imported to fulfill current energy demand (Keffer et al., 2009).

Given the geographic isolation of the state, there have been attempts to establish food and energy self-sufficiency in Hawaii through legislation, research and agricultural initiatives. Factors including land, labor and transportation have thwarted the growth of a thriving agricultural sector (Arita et al., 2012; Parcon et al., 2010; Suryanata, 2000; Yu and Leung, 2012). Food consumption in the state has exceeded local production making Hawaii less food self-sufficient (Leung and Loke, 2008). Recently a state strategic/functional plan was prepared, entitled, "Increased Food Security and Food Self-Sufficiency Strategy" (Department of Business Economic Development and Tourism, 2012). Over the last 50 years, Hawaii's agricultural sector has become more diversified (Cai and Leung, 2006), especially since the decline in production of sugar and pineapple. Initiatives are more visible at the county level. Efforts in the County of Hawaii have focused on the production of food for local consumption. In 2007, the Omidyar Family Foundation funded the Hawaii Whole System Project, which aimed to identify the barriers to more local production and consumption (Page et al., 2007). In 2010 the County of Hawaii updated its 1992 Agricultural Development Plan. This report called for a baseline study "to determine the current inventory of resources on Hawaii Island as they relate to increased food production including land, water, labor, energy, materials and supplies" (The Kohala Center, 2010). This lead to the Hawaii County Food Self-Sufficiency Baseline (Melrose and Delparte, 2012), which created a digital archive of current agricultural activity. This study informed the Hawaii Island Crop Probability Map (Kemp, 2012) which uses a Maximum Entropy modeling technique to find locations where similar crops could have existed on the island of Hawaii. Other studies have been conducted to better understand agricultural markets and stakeholders (Suryanata, 2002). Most recently a study was conducted to set benchmark estimates for Hawaii's food consumption and supply sources, allowing agricultural production for local consumption (Loke and Leung, 2013) to be better targeted.

This analysis considers three scenarios of varying degrees of food and energy selfsufficiency on the island of Kauai. Scenario planning is common in planning and policy practice. While most scenario-based planning is futuristic, practice of multiple scenarios is growing, selecting a single best scenario among a variety of alternatives (Lowry and Kim, 2003). Scenarios can also be thought of as objects or sets of objects that create transitions between past, present and future while constructing new social understandings (Curry, 2009; Hayward and Morrow, 2009). Scenario based planning is based on the assumption of possible change, which helps decision makers understand and assess alternative actions and uncertainties (Shearer, 2005), helping them to rehearse decisions before they happen (Hayward and Morrow, 2009). Normally, scenarios emphasis the role of experts, which may not be appropriate to reflect the social context and uncertainties in the course of scenarios (Curry, 2009). Greater participation by communities impacted by decisions made in the scenarios may be more relevant than expert opinion. Scenarios can be constructed simply as reasoned judgment and intuition, or as sophisticated as structured probabilistic algorithms and simulation (Khakee, 1991). Scenarios in this study are semi-structured while incorporating community preferences. Literature on scenario based analyses can be found in both biofuel production (Wise et al., 2014) and food self-sufficiency (Desjardins et al., 2010). Little research, unfortunately, is focused on island states where the energy and food selfsufficiency is most critical because of isolation from the rest of the world. Few studies cover 
food and energy self-sufficiency simultaneously and provides trade-off scenarios. This paper addresses these knowledge gaps.

This paper informs active policy discussions regarding food and energy independence in Hawaii, and specifically for the island of Kauai. The University of Hawaii received a grant from the County of Kauai to develop and implement a process for evaluating important agricultural lands. There have been several legislative attempts by the state and local governments to move towards increased local production of both food and energy, though the research about the potential of either is lacking, especially at the local level. The objective is to assess the food and energy production possibilities for the island of Kauai using Geographic Information Systems (GIS) and community preferences. Based on a review of the literature, community meetings, and expert interviews, three scenarios were developed to assess food and energy production possibilities on Kauai. The first scenario considers maximum food production, the second assigns equal importance to food and energy production, and the third scenario maximizes energy production.

\section{Food and Energy Policy in Hawaii}

There is a long history of agricultural legislation in Hawaii. In 1978, Article XI, Section 3 of the Hawaii State Constitution was enacted requiring the conservation and protection of agricultural lands to "promote diversified agriculture, increase agricultural selfsufficiency and assure the availability of agriculturally suitable lands." This mandate requires that lands identified by the State needed to fulfill the aforementioned criteria cannot be reclassified without legislative approval. In 2005 additional legislation (Act 183) was passed to provide standards, criteria and processes to identify important agricultural lands. In 2008 Act 233 created incentives to identify, map and designate these important agricultural lands.

Acts 183 and 233 are meant to identify and protect important agricultural lands and increase the viability of diversified agriculture through the expansion of income and job opportunities, while increasing food and energy security. These goals are supported by government agencies which fund or administer programs that support food production, incentivize local procurement, raise community participation, educate producers and create plans that affect land use.

As for energy production, there are nine Hawaii State laws that govern the development of biofuels. ${ }^{1}$ Biofuels are liquid fuels extracted from biomass. Feedstock includes crops, forestry resources, residues, cooking oils, etc (Murphy et al., 2011). The replacement of fossil fuels with biofuels has been promoted for many years, especially in transportation sectors.. Biofuels are likely to be coupled with other alternative fuels including electricity, hydrogen, biogas and natural gas (Murphy et al., 2011) to mitigate greenhouse gas emissions and to meet the increasing energy demand.

Hawaii's Act 183 (2005) includes energy production as part of the criteria for identifying important agricultural lands. Hawaii has one of the most aggressive alternative fuel mandates in the US (Mochizuki, 2013). As part of the Hawaii Clean Energy Initiative, the State has signed a memorandum of understanding with the U.S. Department of Energy to promote the production of $70 \%$ of the state's energy needs from energy-efficient and renewable sources by 2030 (Braccio and Finch, 2011). This initiative was designed to make Hawaii a model for other states to learn how to build a workforce with the cross-cutting skills required to support a clean energy economy. In December 2012, the Hawaii Department of Business, Economic Development and Tourism submitted to the Legislature the final report

\footnotetext{
${ }^{1}$ http://www.afdc.energy.gov/laws/state_summary/HI
} 
on how to significantly expand biofuel production to replace petroleum-based fuels.

\section{Methods for Prioritizing Important Agricultural Lands}

Act 183 established eight criteria to designate agricultural lands as "important agricultural lands." The legislation did not identify these lands. The study team worked with the community to define and rank the criteria, identify which lands best met these criteria and score zoned agricultural lands accordingly. The eight criteria are:

1. Land currently used for agricultural production (Currently in farming);

2. Land with soil qualities and growing conditions that support agricultural production of food, fiber, or fuel- and energy-producing crops (Soil qualities);

3. Land identified under agricultural productivity rating systems, such as the agricultural lands of importance to the State of Hawaii (ALISH) system adopted by the Board of Agriculture on January 28, 1977 (Rating systems);

4. Land types associated with traditional native Hawaiian agricultural uses, such as taro cultivation, or unique agricultural crops and uses, such as coffee, vineyards, aquaculture, and energy production (Traditional and unique farming);

5. Land with sufficient quantities of water to support viable agricultural production (Water availability);

6. Land whose designation as important agricultural lands is consistent with general, development, and community plans of the county (County plans);

7. Land that contributes to maintaining a critical land mass important to agricultural operating productivity (Critical Landmass); and

8. Land with or near support infrastructure conducive to agricultural productivity, such as transportation to markets, water, or power (Supporting infrastructures).

Act 183 allowed for two different procedures for establishing important agricultural lands. One approach requires that landowners file a petition to State Land Use Commission for designation. The second approach is a County led process, in which the County must devise and implement a community process for the designation of important agricultural lands in its jurisdiction. This paper is the output of the second process. 
Figure 1: Study area

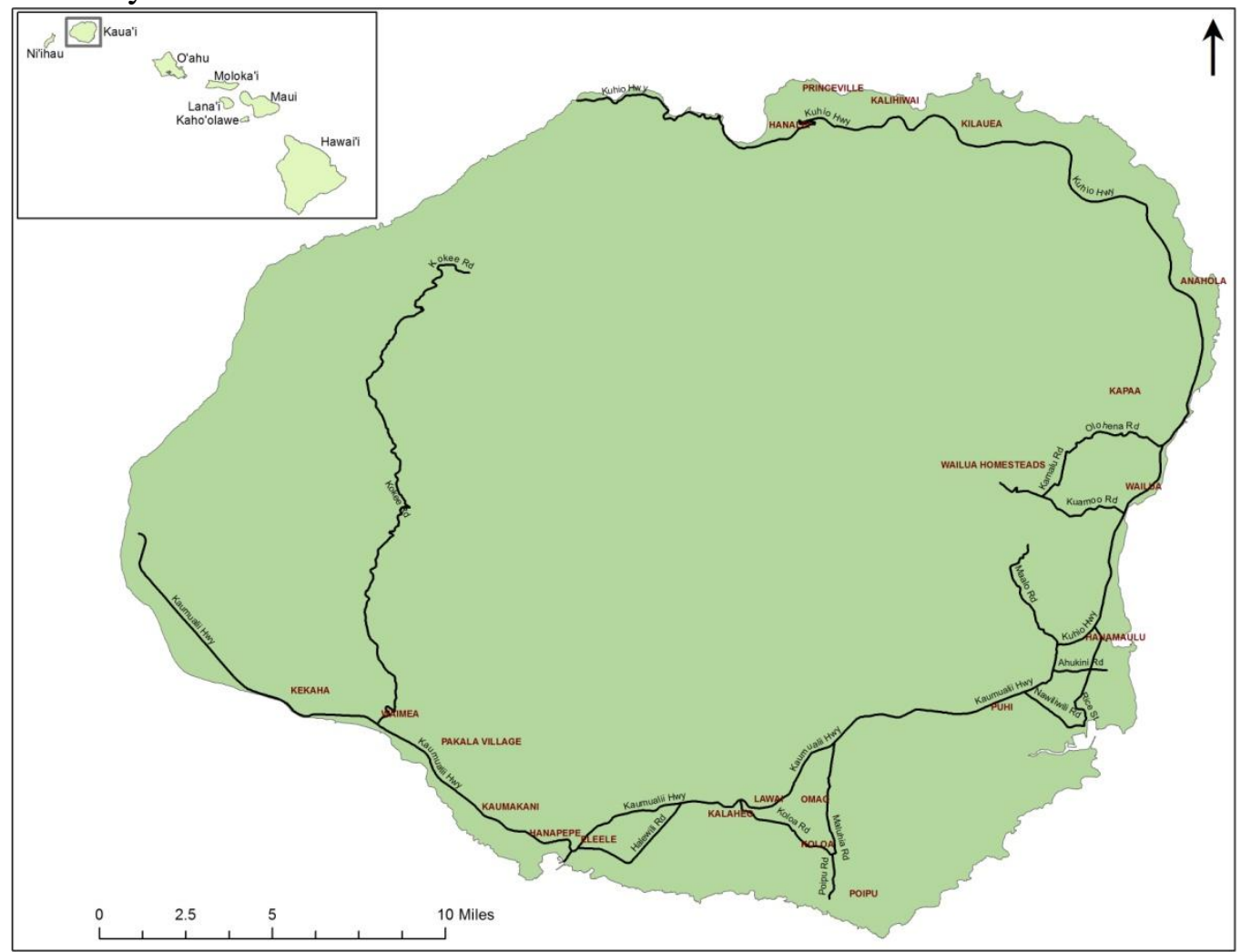

A 21 member Stakeholder Technical Advisory Committee (STAC) was established by the County, with representation from farmers, landowners, agricultural entrepreneurs, community leaders, agricultural technical experts, and extension agents. The study team worked closely with this committee. Previous studies which used expert opinion in the course of determining food self-sufficiency (Desjardins et al., 2010) were reviewed. A total of 18 formal meetings were organized with the STAC to define and operationalize the legislative criterion and rank them through extensive pair-wise comparisons and other ranking techniques. The committee identified more than 20 sub-criteria to more precisely define the eight general legislative criteria. Six regional community meetings were conducted to gather additional feedback from the broader communities. This provided additional data to verify rankings and improve STAC deliberations. Sample parcels were presented with combinations of IAL criteria, and STAC members were asked to compare them to each other. Eight criteria were consolidated to three categories as water related, crop related and land related. There were 30 pair-wise comparisons made to derive weights for each criterion. The comparison results were analyzed using the Analytic Hierarchy Process (AHP). The criteria weights were normalized with a maximum of 10 . The sub-criteria weights were compared among subcriteria of the respective criterion with maximum value of 1 . This was achieved through a structured survey among STAC members. In parallel of the community process, spatial data of each sub-criterion was analyzed using geographic information system (GIS). Simple maps of each sub-criterion were generated and were presented to the STAC and broader Kauai community for improvement and verification. Similarly, local agricultural experts were interviewed and consulted to calculate crop and animal productivity on Kauai. Those data were integrated into GIS files of each criterion. The linear combination method (Basnet et al., 2001; Eastman et al., 1998; Thapa and Murayama, 2008) of scoring was used to combine 
spatial data of each criterion to calculate a score for each agricultural parcel based on the eight legislative criteria. The following equation illustrates how linear combination scores for important agricultural lands (IAL) were derived:

where,

$$
\sum \mathrm{I}_{1} \mathrm{~W}_{1}+\mathrm{I}_{2} \mathrm{~W}_{2}+\ldots .+\mathrm{I}_{8} \mathrm{~W}_{8} \ldots \ldots \ldots \ldots \ldots \ldots . . \ldots q .1
$$

$$
\begin{aligned}
& \mathrm{I}=\text { Sub-criteria value }(0 \text { to } 1) \\
& \mathrm{W}=\text { Weight for criteria from AHP (1.8 to } 10)
\end{aligned}
$$

In the process of prioritizing agricultural lands by STAC members, the highest ranked criterion was the availability of water. This included irrigation from reservoirs, ditches, streams, agricultural wells, and rainfall. STAC members ranked reservoirs and ditches as the most reliable sources of water. Interestingly, the least important criterion was the consistency of agricultural boundaries with county plans. County plans were operationalized to include

\begin{tabular}{|c|c|c|c|c|}
\hline Criteria & $\begin{array}{c}\text { Criteria } \\
\text { weight } \\
\text { (W) }\end{array}$ & Sub-criteria & $\begin{array}{c}\text { Sub- } \\
\text { criteria } \\
\text { index (I) }\end{array}$ & $\begin{array}{l}\text { Criteria } \\
\text { Score } \\
(\mathrm{W} \times \mathrm{I})\end{array}$ \\
\hline \multirow{3}{*}{$\begin{array}{l}\text { 1. Currently in } \\
\text { farming }\end{array}$} & \multirow{3}{*}{5.4} & Cultivated/fallow land & 1 & 5.4 \\
\hline & & Ranching/grazing & 0.78 & 4.21 \\
\hline & & Idle land & 0 & 0 \\
\hline \multirow{3}{*}{ 2. Soil qualities } & \multirow{3}{*}{6.3} & Historic farmland & 1 & 6.3 \\
\hline & & $\begin{array}{l}\text { Appropriate soil for agriculture } \\
\text { (Prime farmlands) }\end{array}$ & 1 & 6.3 \\
\hline & & Other lands & 0 & 0 \\
\hline \multirow{3}{*}{ 3. Rating systems } & \multirow{3}{*}{5.9} & ALISH & 1 & 5.9 \\
\hline & & LSB A and B classes & 1 & 5.9 \\
\hline & & Other lands & 0 & 0 \\
\hline \multirow{4}{*}{$\begin{array}{l}\text { 4. Traditional and } \\
\text { unique farming }\end{array}$} & \multirow{4}{*}{3.7} & Hawaiian taro farming & 1 & 3.7 \\
\hline & & Historic Taro predictive model & 0.55 & 2.03 \\
\hline & & Unique crops farming & 0.53 & 1.96 \\
\hline & & Other lands & 0 & 0 \\
\hline \multirow{7}{*}{$\begin{array}{l}\text { 5. Water } \\
\text { availability }\end{array}$} & \multirow{7}{*}{10} & Reservoirs and/or ditches & 1 & 10 \\
\hline & & Streams, wells and rainfall & 0.74 & 7.4 \\
\hline & & Streams and wells/rainfall & 0.70 & 7 \\
\hline & & Wells and rain & 0.60 & 6 \\
\hline & & Stream only & 0.40 & 4 \\
\hline & & Well only & 0.34 & 3.4 \\
\hline & & Other lands & 0 & 0 \\
\hline \multirow[t]{2}{*}{ 6. County plans } & \multirow[t]{2}{*}{1.8} & $\begin{array}{l}\text { Consistency with County Zoning } \\
\text { and General Plan }\end{array}$ & 1 & 1.8 \\
\hline & & $\begin{array}{l}\text { Not consistent with County Zoning } \\
\text { and General Plan }\end{array}$ & 0 & 0 \\
\hline \multirow{2}{*}{$\begin{array}{l}\text { 7. Critical } \\
\text { landmass }\end{array}$} & \multirow{2}{*}{3.3} & 4 or more 16 acres cells together & 1 & 3.3 \\
\hline & & 1 or 2 or 316 acres cells together & 0 & 0 \\
\hline
\end{tabular}
county zoning ordinances, development plans, and the general plan mandates.

Table 1: Evaluation of criteria and sub-criteria by STAC 


\begin{tabular}{|c|c|c|c|c|}
\hline \multirow{6}{*}{$\begin{array}{l}\text { 8. Supporting } \\
\text { infrastructures }\end{array}$} & \multirow{6}{*}{3.9} & $\begin{array}{l}\text { Agricultural land within } 1 / 4 \text { a mile } \\
\text { from road and within } 5 \text { miles from } \\
\text { harbor }\end{array}$ & 1 & 3.9 \\
\hline & & $\begin{array}{l}\text { Ag. land within } 1 / 4 \text { a mile from road } \\
\text { and within } 5-10 \text { miles from harbor }\end{array}$ & 0.75 & 2.92 \\
\hline & & $\begin{array}{l}\text { Ag. land within } 1 / 4 \text { a mile from road } \\
\text { and beyond } 10 \text { miles from harbor }\end{array}$ & 0.5 & 1.95 \\
\hline & & $\begin{array}{l}\text { Ag. land beyond } 1 / 4 \text { a mile from road } \\
\text { and within } 5 \text { miles from harbor }\end{array}$ & 0.9 & 3.51 \\
\hline & & $\begin{array}{l}\text { Ag. land beyond } 1 / 4 \text { a mile from road } \\
\text { and within } 5-10 \text { miles from harbor }\end{array}$ & 0.67 & 2.63 \\
\hline & & $\begin{array}{l}\mathrm{Ag} \text {. land beyond } 1 / 4 \text { a mile from road } \\
\text { and beyond } 10 \text { miles from harbor }\end{array}$ & 0.45 & 1.75 \\
\hline \multicolumn{3}{|c|}{ IAL threshold range $\left(\sum \mathrm{I}_{1} \mathrm{~W}_{1}+\mathrm{I}_{2} \mathrm{~W}_{2}+\ldots+\mathrm{I}_{8} \mathrm{~W}_{8}\right)$} & & $0-40$ \\
\hline
\end{tabular}

Table 1 provides detail on the criteria weights and sub-criteria scores. With the combination of all criteria weights and sub-criteria scores, each parcel of agricultural land scored ranging from 0 to 40, with higher scores indicating stronger agreement with the criteria and better land for agricultural use. Once all of the parcels were scored, the next step was determining the threshold for "important" agricultural lands. The STAC was asked to come to a general agreement regarding how high a score needed to be to be classified as "Important." With incentives such as tax credits and infrastructure improvements at stake, this was a significant part of the process.

Figure 2 presents IAL thresholds and their corresponding agricultural land acreage. Lower threshold allows for more agricultural land, which satisfies a lower number of IAL criteria. The quality of land is lower under the lower thresholds. With the higher threshold, total land deemed IAL will be less, but it meets more criteria so is therefore of higher quality. 
Figure 2: Amount of land corresponding to IAL thresholds

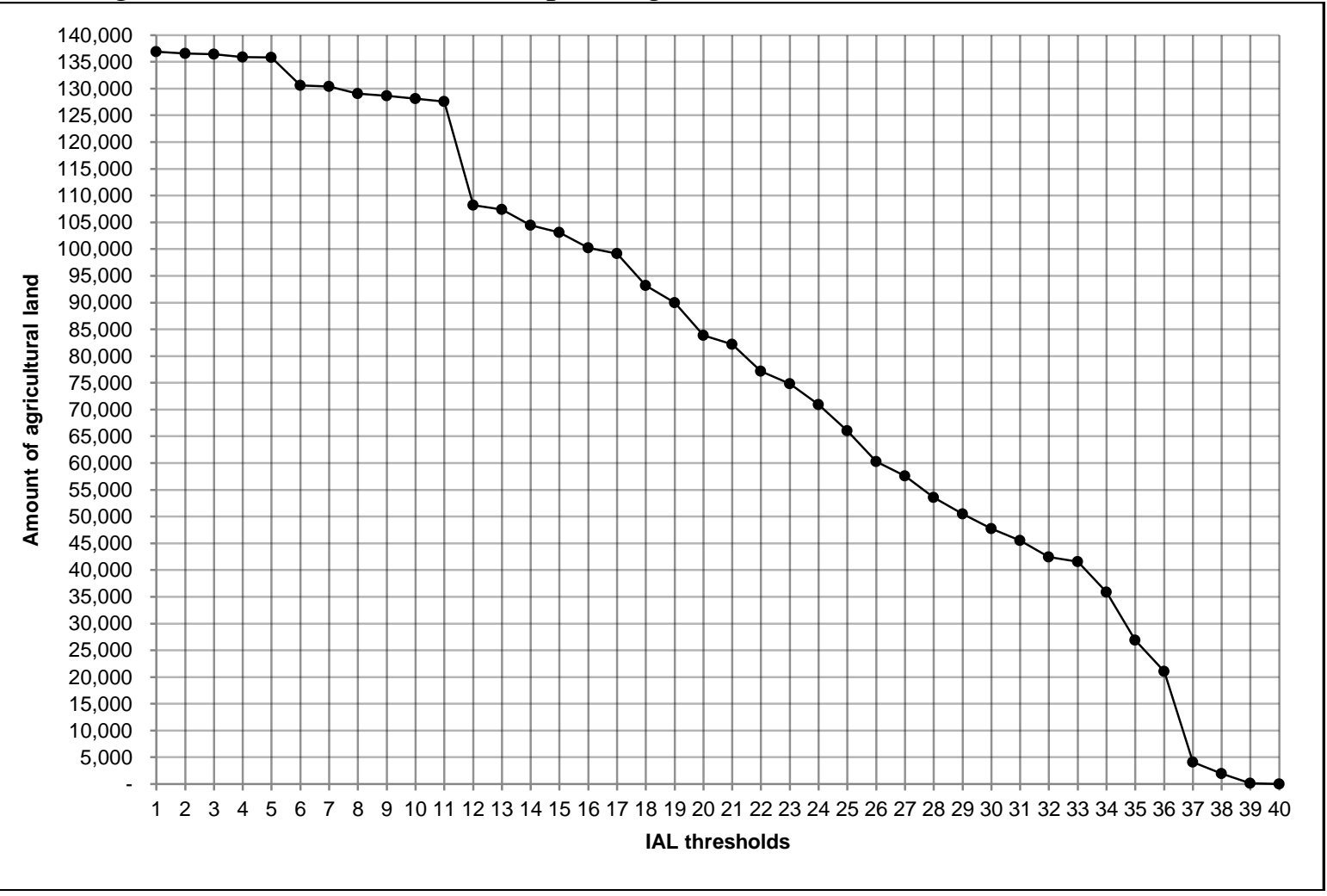

Through several months of discussions with the STAC at committee meetings, it became evident that both food and energy independence were important goals for the community. Before the STAC could come to an agreement regarding a threshold for important agricultural lands, the committee asked the study team to provide an analysis of what these objectives would require in terms of acreage, under a variety of possible threshold levels. Therefore, scenarios targeting food and energy self-sufficiency were designed, under various score thresholds, and presented back to the STAC.

The food self-sufficiency scenarios were calculated based on a 2,500 calorie intake per person per day (Reppun, 2010). This diet does not include micro nutrient analysis, but is very similar to the per capita diet consumption presented by United States Department of Agriculture (USDA). Based on this estimate and the assumptions outlined in Table 2, 0.84 acres of land are required per person for local food self-sufficiency. The food crops selected in Table 2 are based on the local farming practices.

Table 2: Breakdown of food intake and required agricultural lands for food self-sufficiency

\begin{tabular}{|l|c|c|c|c|}
\hline & $\begin{array}{l}\text { Per person } \\
\text { annual food } \\
\text { requirement } \\
\text { (bs/person/year) }\end{array}$ & $\begin{array}{l}\text { Average yield } \\
\text { (bs/acre/year) }\end{array}$ & $\begin{array}{l}\text { Amount of food } \\
\text { for 67,091 } \\
\text { people (lbs/year) }\end{array}$ & $\begin{array}{l}\text { Required } \\
\text { acres/year }\end{array}$ \\
\hline $\begin{array}{l}\text { FRUITS (citrus, } \\
\text { banana, papaya, } \\
\text { pineapple) }\end{array}$ & 365 & 10,000 & $24,488,215$ & $2,448.82$ \\
\hline $\begin{array}{l}\text { VEGETABLES } \\
\text { (Tomatoes, broccoli, }\end{array}$ & 365 & 60,000 & $24,488,215$ & 408.14 \\
\hline
\end{tabular}




\begin{tabular}{|l|c|c|c|c|}
\hline $\begin{array}{l}\text { mustard cabbage, } \\
\text { lettuce, zucchini) }\end{array}$ & & & & \\
\hline STARCH & & & & \\
\hline Potato/taro & 100 & 25,000 & $6,709,100$ & 268.36 \\
\hline Rice/grain & 200 & 2,500 & $13,418,200$ & $5,367.28$ \\
\hline MEAT & & & & \\
\hline Beef & 64.10 & 119.0 & $4,300,533$ & $36,138.93$ \\
\hline Fish & 91.25 & 25,000 & $6,122,054$ & 244.88 \\
\hline Chicken & 83.90 & 1,129 & $5,628,935$ & $4,985.77$ \\
\hline Pig & 48.90 & 852 & $3,280,750$ & $3,850.65$ \\
\hline DAIRY (Milk) & 182.50 & 6,000 & $12,244,108$ & $2,040.68$ \\
\hline EGGS* & 170.40 & 17,221 & $11,432,306$ & 663.86 \\
\hline $\begin{array}{l}\text { Total land for food } \\
\text { self-sufficiency }\end{array}$ & & & & \\
\hline
\end{tabular}

*Number of eggs.

Notes:

Based on (Reppun, 2010) \& communication with local experts by authors, 2012-13

To assess the energy self-sufficiency objective, the analysis replaced highway fuel consumption with biofuels and electricity generated from conventional fossil fuels with solar sources. Annual highway fuel consumption in 2009 was 51.59 million gallons (Department of Business Economic Development and Tourism, 2009). Research has found that the mileage with E85 fuel decreases by $25-30 \%$ (West et al., 2007). Based on 30\% less efficiency of biofuel compared to gasoline, we calculated that 67.05 million gallons of ethanol are necessary to replace the current highway fuel use.

Crops were identified for energy production based on studies conducted in Hawaii. Slope, soil type and the water sources are determining factors for ethanol producing crops (Easterly et al., 2010). GIS has been used to assess the suitability of land for energy crops (Easterly et al., 2010; Keffer et al., 2006). STAC members established proxy criteria for slope and soils. Lands that are or have been farmed in the past, have good soils and slope for banagrass production. Irrigation sources, however, can vary. The availability of irrigation for farming became the determining factor for energy crops. Five irrigation sources were identified, including ditches, reservoirs, rainfall, wells, and streams. Ditches and reservoirs were ranked most important. The STAC determined that ditches and reservoirs are the most reliable sources of irrigation. Banagrass needs more than 78 inches of annual rainfall or a reliable source of irrigation (Keffer et al., 2006) therefore lands in current cultivation, fallow lands and historical sugarcane lands with more than 78 inches of irrigation are set aside for banagrass production. Oil palm requires the same amount of irrigation as banagrass. Historically farmed land with any other crop that is not being used for food production and banagrass production was assigned oil palm farming. Eucalyptus requires less water than banagrass or oil palm. More than 40 inches of rainfall is sufficient for eucalyptus (Keffer et al., 2006), therefore any remaining agricultural land with more than 40 inches of rainfall annually was assigned eucalyptus farming after assigning food, banagrass, and oil palm production. Leucaena needs the least amount of rainfall, between 20-40 inches (Keffer et al., 2006), therefore any agricultural land with more than 20 inches of rainfall that are not being used for food production, banagrass, oil palm or eucalyptus farming was assigned to leucaena production. 
For solar farming, land with less than 5\% slope (Helm and Burman, 2010) that is appropriate for leucaena farming and classified as B or C class land by the Hawaii Land Study Bureau (LSB) classification of 1967 is assigned. With a $4.65 \mathrm{kWh} / \mathrm{sq} . \mathrm{m} /$ day generation rate (Department of Planning and Economic Development, 1985), 64 acres of land are necessary for solar photovoltaic to replace the electricity generated through conventional fuel (Diesel). Because of the inequality of solar radiation throughout the island, 100 acres of land is set aside for photovoltaic. In each threshold, there is more than 100 acres of land appropriate for solar farming under LSB B and C classes. The extra land that meets the solar farming criteria is assigned to leucaena production. The ethanol productivity of each energy crop is also not uniform. Among the four crops, banagrass has the highest productivity. The productivity of banagrass, oil palm (biodiesel), eucalyptus, and leucaena is 1440.5, 203.4, 507, and 572 gallons per acres per year, respectively (Tran et al., 2011).

\section{Findings}

In order to evaluate the availability of agricultural lands for food and biofuel crops production, we designed three scenarios. The scenarios were created to assess food and energy self-sufficiency based on available agricultural lands under different IAL thresholds. These scenarios are: food self-sufficiency, energy self-sufficiency, and balanced food and energy production. The scenarios were built to facilitate community deliberations in determining the appropriate amount of land to be designated as important agricultural lands, based on Act 183 criteria. When asked to choose the appropriate threshold for IAL, the STAC requested attention to the achievement of food and energy security goals, and how the IAL scores could meet these goals. Each scenario analyzed food and energy production under three IAL thresholds (low, medium, and high). Higher threshold implied more stringent criteria, decreasing the amount of available land. IAL scores ranged from 0 to 40 points based on equation (1). The available agricultural land for the low, medium and high thresholds is 128,093 acres, 83,865 acres and 47,740 acres respectively. The total amount of agricultural land is 136,908 acres. Food self-sufficiency is possible under the low and medium thresholds in the first scenario and under the low threshold only in the second scenario. The ranges of threshold show the quality of land for agricultural practices based on the 8 criteria. Lower threshold means agricultural land meets lower number of criteria. Energy self-sufficiency can be achieved under the low and medium thresholds in the third scenario. These results are presented in the shaded cells of Table 3 . The best agricultural lands are set aside for food production in every scenario. This reduces the food-fuel competition of bio-productive lands (Johansson and Azar, 2007).

Although the priority of the third scenario is energy self-sufficiency, the best lands are still used for food production under low and medium thresholds, where there is remaining land after supporting energy self-sufficiency. Regarding biofuel production, each scenario substitutes highway fuel use with biofuel. It does not consider non-highway fuel use. The replacement level is calculated based on per vehicle average fuel consumption. In the case of solar energy, these scenarios replace petroleum-generated electricity with photovoltaic electricity. These scenarios were designed to help STAC members evaluate the consequences of different IAL scores on local food and energy production, so they could choose an appropriate threshold to recommend to the county to deem lands "IAL." 
Table 3: Details of food and energy self-sufficiency

\begin{tabular}{|c|c|c|c|c|c|c|c|c|c|}
\hline \multirow{2}{*}{ Description } & \multicolumn{3}{|c|}{$\begin{array}{l}\text { Scenario A: } \\
\text { Prioritizing food self-sufficiency for } \\
\text { current population (Census 2010) }\end{array}$} & \multicolumn{3}{|c|}{$\begin{array}{c}\text { Scenario B: } \\
\text { Balanced food and energy } \\
\text { production }\end{array}$} & \multicolumn{3}{|c|}{$\begin{array}{c}\text { Scenario C: } \\
\text { Prioritizing energy self- } \\
\text { sufficiency for highway use } \\
\end{array}$} \\
\hline & Low & Medium & High & Low & Medium & High & Low & Medium & High \\
\hline Available agricultural land (Acres) & 128,093 & 83,865 & 47,740 & 128,093 & 83,865 & 47,740 & 128,093 & 83,865 & 47,740 \\
\hline Food production (Acres) & 56,417 & 56,417 & 47,740 & $64,046.5$ & $41,932.5$ & 23,870 & 32,583 & 13,162 & - \\
\hline $\begin{array}{l}\text { - Potential self-sufficient } \\
\text { population }\end{array}$ & 67,091 & 67,091 & 56,766 & 76,175 & 49,873 & 28,390 & 38,753 & 15,654 & - \\
\hline Solar farming (Acres) & 100 & 100 & - & 100 & 100 & 100 & 100 & 100 & 100 \\
\hline $\begin{array}{l}\text { - Solar electricity production } \\
\text { (in LSB B or C land, MWh/day) }\end{array}$ & 1,883 & 1,883 & - & 1,883 & 1,883 & 1,883 & 1,883 & 1,883 & 1,883 \\
\hline Ethanol production (Acres) & 71,576 & 27,348 & - & $63,946.5$ & $41,832.5$ & 23,770 & 95,410 & 70,603 & 47,640 \\
\hline $\begin{array}{l}\text { - Ethanol production (million } \\
\text { gallons/year) }\end{array}$ & 43.50 & 18.91 & - & 37.30 & 32.52 & 27.72 & 67.05 & 67.05 & 58.62 \\
\hline
\end{tabular}

Notes:

- In each scenario, the highest scoring lands are set aside for food production.

- For solar production, the average potential of electricity generation by using PV is $4.65 \mathrm{kWh} / \mathrm{sq}$. m/day in Kauai (based on State of Hawaii data: http://files.hawaii.gov/dbedt/op/gis/data/solrad.pdf). There was 1,195 $\mathrm{MWh} /$ day electricity consumption from fossil fuel in Kauai in 2009 (Department of Business Economic Development and Tourism, 2009). In order to replace this electricity consumption, precisely 64 acres of solar farming can be enough. 100 acres of agricultural lands is set aside to replace electricity from fossil fuel in Kauai.

- In scenario 3, the 67.05 million gallons of biofuel can be able to replace highway fuel use in Kauai in 2009 (Department of Business Economic Development and Tourism, 2009). 
In Table 3, there are three scenarios with low, medium and high thresholds for each scenario. The low, medium and high thresholds correspond to 10, 20 and 30 points scores as shown in Figure 2. In each threshold under every scenario, if there are agricultural lands available for energy production, 100 acres is set aside for the solar photovoltaic installation. This will be enough to replace the electricity generated from petroleum use. Since solar installation needs relatively flat land, Land Study Bureau (LSB) B and C lands were considered for solar installation. There are 5 categories of LSB lands (A to E) in which A presents the best land for agricultural use.

\section{a. Scenario A: Prioritizing Food Self-Sufficiency}

Under Scenario A, enough agricultural land to meet food requirements is set aside first, and the remaining agricultural lands are assigned to energy production (biofuels and solar photovoltaic installation). Based on the 2010 census, the total residential population of Kauai is 67,091. Under assumptions detailed in Table 2, 56,417 acres of land are required to feed that population locally. Under the low threshold, there is 128,093 acres agricultural land available (Figure 2). Out of that, 71,676 acres of land will be available for energy production after setting aside 56,417 acres land for local food production. Under the medium threshold, the same amount of land is set aside for food production and the remaining 27,448 acres of agricultural land is used for energy production. With population growth, land from energy production would be transferred to food production in order to meet growing demand for food from the additional population. This provides flexibility to incorporate the de-facto tourist population in the food self-sufficiency calculation in order to make the island completely food self-sufficient. Under the high threshold, the total available land is 47,740 acres which is not enough to meet food self-sufficiency for the current population. Under this threshold, 56,766 people can be self-sufficient. Therefore, there is no agricultural land left for energy production under the high threshold in first scenario.

\section{b. Scenario B: Balancing Food and Energy Production}

Scenario B places equal value on food and energy production. Available land for each threshold score is divided equally between food and energy production. In case of the low threshold, both food and energy have 64,046.5 acres of agricultural lands each. Regardless of current population, this scenario puts all 64,046.5 acres of land in food production and estimates the number of people to be self-sufficient based on per person land requirement for self-sufficiency. With that, 76,175 people will be self-sufficient in food from 64,046.5 acres of land. In the case of energy, 63, 946.5 acres will be available for energy crops and 100 acres will be for the solar photovoltaic installation. This is true under all scenarios and thresholds where there is land for energy production. The energy crops will be able to produce 37.30 million gallons of biofuel annually from that land in the low threshold. In the medium threshold, both - energy production and food production - get 83,865 acres each. With that land, only 49,873 people will be self-sufficient in food, which is not enough to make the current population self-sufficient. Similarly, only 32.52 million gallons of ethanol can be produced from 41,832.5 acres of agricultural land. In the case of the high threshold, food and energy production gets only 23,870 acres each. Only 28,390 people will be selfsufficient from that land and 27.72 million gallons of ethanol will be produced. This scenario is rigid for food and energy self-sufficiency, as there is less flexibility to transfer land from energy to food production or vise versa. This scenario can support food self-sufficiency under the low threshold. However if the population expands to over 76,175 in the future, this scenario cannot achieve food self-sufficiency even under the low threshold score. 


\section{c. Scenario C: Prioritizing Energy Self-Sufficiency for Highway Use}

Scenario $\mathrm{C}$ gives priority to energy production. Sufficient land is set aside for biofuel and solar production first, and the remaining land is used for food production. It targets energy self-sufficiency for highway fuel use (defined as 67.05 million gallons of biofuel replacing total highway fuel use) and electricity that is generated from conventional fossil fuels. Even though energy self-sufficiency is the priority of this scenario, the best land is stilled used for food production if there is more agricultural land than required for energy production. Under the low threshold, 95,410 acres of land will be sufficient to produce 1883 $\mathrm{MWh}$ /day and 67.05 million gallons of ethanol per year. That is sufficient to replace the highway fuel use and electricity generated from conventional fossil fuel. The total acreage under the low threshold is 128,093 acres. The remaining 32,583 acres of agricultural land will be used for food production and it will make 38,753 people self-sufficient in food in the low threshold. In the medium threshold, 70,603 acres of land will be sufficient to produce 67.05 million gallons of ethanol and $1883 \mathrm{MWh}$ /day electricity from solar photovoltaic. In this threshold, less land is sufficient to produce energy because of the higher productivity lands in this threshold. The higher the threshold, the higher the quality. Once the 70,603 acres of land is used for energy production out of 83,865 acres of total agricultural lands under the medium threshold, 13,162 acres will remain for food production that will make 13,162 people self-sufficient in food. Under the high threshold, there is an only 47,740 acres of land available. From that land, 58.62 million gallons of ethanol can be produced along with 1,883 MWh/day electricity from photovoltaic. Although it meets the self-sufficiency range for electricity production, it cannot replace the highway fuel use completely. Therefore, there is not any land left for food production under this threshold. Another assumption of this scenario is if energy demand increases, the land from food production is transferred to energy production to meet the extra demand under each threshold.

\section{Conclusions}

Increasing local production of food and energy is an important goal for communities around the world. This paper examines the potential for Kauai to meet the nutritional and energy demands of its population. Three scenarios are examined: complete food selfsufficiency, a balance between food and energy production, and a focus on meeting existing energy needs. Our analysis shows that while the currently zoned agricultural lands on Kauai are capable of meeting the nutritional needs of the current population, even when setting high quality requirements for the agricultural lands, it is not possible to meet the total energy demands of the island unless lower quality agricultural lands are used.

Under Scenario A (prioritize food production), we find that food self-sufficiency needs can be met under the low (10) and medium (20) IAL thresholds, but not when faced with the limited but highest quality lands under the 30-point threshold. When food and energy needs are given equal priority, food self-sufficiency for the current population can only be met under the least restrictive IAL threshold of 10 points. When energy selfsufficiency is the goal (Scenario C), food self-sufficiency is not possible under any assumption of IAL thresholds.

This paper provides a framework, methods, and tools for the assessment of lands for meeting food and energy needs. While this research has focused on Kauai, the approach could be modified for other crops, agricultural systems, and communities elsewhere in the world. It would be most interesting to see comparative applications of these methods especially in communities interested in boosting self-sufficiency and resilience. It has also provided critical information to inform the policy discussion on Kauai and in Hawaii on the challenges with achieving food and energy independence. While both food and energy 
independence are touted as important policy goals, when the quality or quantity of land is limited, there are important tradeoffs that should be considered when striving for either or both of these goals. Our methods provide a transparent, community-oriented process for determining which of these goals is most important, and clearly illustrates the tradeoffs in attempting to achieve them.

\section{ACKNOWLEDGEMENTS}

We are thankful to County of Kauai Planning Department, Stakeholder Technical Advisory Committee, Kauai Farm Service Agency, University of Hawaii Cooperative Extension Service Kauai Extension Office, Peter Nakamura, Nadine Nakamura, Made I. Brunner, Leanora Kaiaokamalie, Micahel Dahilig, Ian Jung, Ian Costa, Matthew Stevenson, Robert Ishikawa, Lauren Armstrong, and the Kauai community for their support to complete this project.

\section{References}

Arita, S., Naomasa, E., Leung, P., 2012. Comparison of Cost Structure and Economic Performance of Hawai'i and U.S. Mainland Farms, Economic Issues. College of Tropical Agriculture and Human Resources, Honolulu, Hawaii.

Basnet, B.B., Apan, A.A., Raine, S.R., 2001. Selecting suitable sites for animal waste application using a raster GIS. Environmental Management 28, 519-531.

Braccio, R., Finch, P., 2011. HCEI Road Map: 2011 Edition. US Department of Energy, Oak Ridge, Tennessee.

Cai, J., Leung, P., 2006. Growth and Stability of Agricultural Production in Hawaii: A Portfolio Analysis, Economic Issues. College of Tropical Agriculture and Human Resources, Honolulu, Hawaii.

College of Tropical Agriculture and Human Resources, 2009. Hawaii Bioenergy Master Plan. University of Hawaii at Manoa, Honolulu.

Cunningham, C., 2010. Hawai'i Food Policy Council: A Tool for Food System Planning, Department of Urban and Regional Planning. University of Hawaii at Manoa, Honolulu, Hawaii.

Curry, A., 2009. From Foresight to Insight: Using Scenarios Well. Journal of Futures Studies $13,119-122$.

Department of Business Economic Development and Tourism, 2006. Photovoltaic Electricity in Hawaii, in: Department of Business, E.D., and Tourism,, Hawaii, S.o. (Eds.). Department of Business, Economic Development, and Tourism,, Honolulu.

Department of Business Economic Development and Tourism, 2009. The State of Hawaii Data Book 2009. Department of Business, Economic Development and Tourism, Honolulu, Hawaii.

Department of Business Economic Development and Tourism, 2012. Increased Food Security and Food Self-Sufficiency Strategy. Department of Business, Economic Development and Tourism, Honolulu, Hawaii.

Department of Planning and Economic Development, 1985. Sunshine Maps. State Department of Planning and Economic Development, Honolulu.

Desjardins, E., MacRae, R., Schumilas, T., 2010. Linking future population food requirements for health with local production in Waterloo Region, Canada. Agriculture and Human Values 27, 129-140. 
Easterly, J., Cummer, K., Emsick, N., Hunsaker, M., Harper, B., Olson, S., Roush, B., Ogoshi, R., Yanagida, J., 2010. The Potential for Biofuel Production in Hawaii: Report Prepared for Hawaii Department of Business, Economic Development and Tourism. Back \& Veatch Corporation, Kansas.

Eastman, J.R., Jiang, H., Toledano, J., 1998. Multi-criteria and multi-objective decision making for land allocation using GIS, Multicriteria analysis for land-use management. Springer, pp. 227-251.

Feenstra, G.W., 1997. Local food systems and sustainable communities. American journal of alternative agriculture 12, 28-36.

Hayward, P., Morrow, R., 2009. An Integrated Approach to Scenarios. Journal of Future Studies 813, 115-118.

Helm, C., Burman, K., 2010. Kauai, Hawaii: Solar Resource Analysis and High-Penetration PV Potential. National Renewable Energy Laboratory.

Hill, J., 2007. Environmental costs and benefits of transportation biofuel production from food- and lignocellulose-based energy crops. A review. Agron. Sustain. Dev. 27, 1-12.

Johansson, D.J., Azar, C., 2007. A scenario based analysis of land competition between food and bioenergy production in the US. Climatic Change 82, 267-291.

Johnson, F.X., Silveira, S., 2014. Pioneer countries in the transition to alternative transport fuels: Comparison of ethanol programmes and policies in Brazil, Malawi and Sweden. Environmental Innovation and Societal Transitions 11, 1-24.

Keffer, V., Evans, D., Turn, S., Kinoshita, C., 2006. Potential for Ethanol Production in Hawaii. Hawaii Natural Energy Institute and College of Tropical Agriculture and Human Resources, Honolulu, HI.

Keffer, V.I., Turn, S.Q., Kinoshita, C.M., Evans, D.E., 2009. Ethanol technical potential in Hawaii based on sugarcane, banagrass, Eucalyptus, and Leucaena. Biomass and Bioenergy 33, 247-254.

Kemp, K.K., 2012. The Hawaii Island Crop Probability Map: An Update of the Crop Growth Parameters for the Hawaii County Crop Model: Final Report prepared for the County of Hawai i Research and Development Department. USCDornsife, Los Angeles.

Keske, C., Smutko, S., 2010. Consulting communities: using audience response system (ARS) technology to assess community preferences for sustainable recreation and tourism development. Journal of Sustainable Tourism 18, 951-970.

Khakee, A., 1991. Scenario construction for urban planning. Omega 19, 459-469.

Kremer, P., DeLiberty, T.L., 2011. Local food practices and growing potential: Mapping the case of Philadelphia. Applied Geography 31, 1252-1261.

Ladefoged, T.N., Kirch, P.V., Gon Iii, S.M., Chadwick, O.A., Hartshorn, A.S., Vitousek, P.M., 2009. Opportunities and constraints for intensive agriculture in the Hawaiian archipelago prior to European contact. Journal of Archaeological Science 36, 2374-2383.

Leung, P., Loke, M., 2008. Economic Impacts of Increasing Hawaii's Food Self-Sufficiency, Economic Issues. College of Tropical Agriculture and Human Resources, Honolulu, Hawaii.

Loke, M.K., Leung, P., 2013. Hawaii's food consumption and supply sources: benchmark estimates and measurement issues. Agricultural and Food Economics 1, 10.

López-Bellido, L., Wery, J., López-Bellido, R.J., 2014. Energy crops: Prospects in the context of sustainable agriculture. European Journal of Agronomy 60, 1-12.

Lowry, K., Kim, K., 2003. Anticipating Alternative Futures: Using Scenarios for LongRange Planning in Hawaii. Journal of Future Studies 8, 19-30.

MacRae, R.J., Lynch, D., Martin, R.C., 2010. Improving Energy Efficiency and GHG Mitigation Potentials in Canadian Organic Farming Systems. Journal of Sustainable Agriculture 34, 549-580. 
McGrarrell, E., 2005. The Unique Marriage of Emergency Reponse, Supply Chain Management and Food Security, The Institute of Food Technologists' First Annual Food Protection and Defense Research Conference. The Institute of Food Technology, Atlanta, Georgia, USA.

Melrose, J., Delparte, D., 2012. Hawaii County Food Self-Sufficiency Baseline 2012. University of Hawaii at Hilo, Hilo, Hawaii.

Mochizuki, J., 2013. Three Essays on Lignocellulosic Ethanol Development in Hawai' $i$ : Cross-disciplinary Analyses Based on Geospatial, Life-cycle and General Equilibrium Modeling, Department of Natural Resource and Environmental Management. University of Hawaii at Manoa, Honolulu, Hawaii.

Murphy, R., Woods, J., Black, M., McManus, M., 2011. Global developments in the competition for land from biofuels. Food Policy 36, Supplement 1, S52-S61.

Page, C., Bony, L., Schewel, L., 2007. Island of Hawaii Whole System Project Phase I Report. Rocky Mountain Institute, Boulder, Colorado.

Parcon, H., Loke, M., Leung, P., 2010. Costs of Transporting Fresh Fruits and Vegetables to Honolulu from Hilo and Los Angeles, Economic Issues. College of Tropical Agriculture and Human Resources, Honolulu, Hawaii.

Parida, B., Iniyan, S., Goic, R., 2011. A review of solar photovoltaic technologies. Renewable and Sustainable Energy Reviews 15, 1625-1636.

Peters, C.J., Bills, N.L., Lembo, A.J., Wilkins, J.L., Fick, G.W., 2009a. Mapping potential foodsheds in New York State: a spatial model for evaluating the capacity to localize food production. Renewable Agriculture and Food Systems 24, 72.

Peters, C.J., Bills, N.L., Wilkins, J.L., Fick, G.W., 2009b. Foodshed analysis and its relevance to sustainability. Renewable Agriculture and Food Systems 24, 1-7.

Razykov, T.M., Ferekides, C.S., Morel, D., Stefanakos, E., Ullal, H.S., Upadhyaya, H.M., 2011. Solar photovoltaic electricity: Current status and future prospects. Solar Energy 85, 1580-1608.

Reppun, C., 2010. Agriculture, in: Howes, C., Osorio, J.K. (Eds.), The Value of Hawai'i: Knowing the Past, Shaping the Future. University of Hawaii Press, pp. 39-46.

Saaty, T.L., 1980. The Analytic Hierarchy Process. McGraw-Hill USA.

Saaty, T.L., 1982. Decision Making for Leaders: The Analytic Hierarchy Process for Decision in a Complex World. Lifetime Learning Publication, Belmont, California.

Sharma, K.L., 2006. Food security in the South Pacific Island countries with special reference to the Fiji Islands. Research Paper, UNU-WIDER, United Nations University (UNU).

Shearer, A.W., 2005. Approaching scenario-based studies: three perceptions about the future and considerations for landscape planning. Environment and planning B: Planning and Design 32, 67-87.

Sims, R.E.H., Mabee, W., Saddler, J.N., Taylor, M., 2010. An overview of second generation biofuel technologies. Bioresource Technology 101, 1570-1580.

State of Hawaii, 2008a. Hawaii Revised Statute (§196-42), in: Hawaii, S.o. (Ed.). State of Hawaii, Honolulu.

State of Hawaii, 2008b. Hawaii Revised Statute (§269-92), in: Hawaii, S.o. (Ed.). State of Hawaii, Honolulu.

Suryanata, K., 2000. Products from paradise: The social construction of Hawaii crops. Agriculture and Human Values 17, 181-189.

Suryanata, K., 2002. Diversified Agriculture, Land Use, and Agrofood Networks in Hawaii. Economic Geography 78, 71-86. 
Thapa, R.B., Murayama, Y., 2008. Land evaluation for peri-urban agriculture using analytical hierarchical process and geographic information system techniques: A case study of Hanoi. Land Use Policy 25, 225-239.

The Kohala Center, 2010. The 2010 County of Hawaii Agriculture Development Plan. The Kohala Center, Hawaii.

Tran, N., Illukpitiya, P., Yanagida, J.F., Ogoshi, R., 2011. Optimizing biofuel production: An economic analysis for selected biofuel feedstock production in Hawaii. Biomass and Bioenergy 35, 1756-1764.

West, B.H., López, A.J., Theiss, T.J., Graves, R.L., Storey, J.M., Lewis, S.A., 2007. Fuel economy and emissions of the ethanol-optimized Saab 9-5 biopower. SAE paper 1, 3994.

Wise, M., Dooley, J., Luckow, P., Calvin, K., Kyle, P., 2014. Agriculture, land use, energy and carbon emission impacts of global biofuel mandates to mid-century. Applied Energy 114, 763-773.

$\mathrm{Yu}, \mathrm{R}$., Leung, P., 2012. The economic implication of rising transport cost for a small open economy: a case study of Hawaii's vegetable sector. Ann Reg Sci 48, 855-875. 